\title{
One black bear (Ursus americanus) connects the great sierras: Genetic evidence
}

\author{
'Maria Gabriela Camargo-Aguilera, ${ }^{1}$ Nalleli E. Lara-Díaz, ${ }^{1}$ Helí Coronel-Arellano and ${ }^{1}$ Carlos A. López-González \\ ${ }^{1}$ Laboratorio de Zoología, Facultad de Ciencias Naturales, Universidad Autónoma de Querétaro. Avenida de las Ciencias S/N, CP. \\ 76230. Querétaro, México. Email: gaby.camargo9@gmail.com (MGCA), lara.nalleli@gmail.com (NELD), heli.coronelarellano@ \\ gmail.com (HCA), Cats4mex@gmail.com (CALG).Phone: 4421921200 Ext. 5341. \\ *Corresponding author
}

The black bear has inhabited North America for three million years. Two clades diverged during this period: coastal and continental; the continental clade includes two subclasses (western and eastern). The contact between both is a recent event. Because there is a high genetic differentiation between subclasses, the genetic flow of populations between Sierra Madre Oriental and Sierra Madre Occidental is considered as restricted to nonexistent; also, desert environments and human settlements act as a barrier. There are no recent records of black bears in Durango, so the capture of an individual from there presents the opportunity to test whether there is a possible connection between the populations of Sierra Madre Occidental and Sierra Madre Oriental. Our objective was to determine the geographic origin of this individual and validate whether there is a likely connection between populations from both mountain ranges. A black bear specimen was captured in Felipe Carrillo Puerto, municipality of Guadalupe Victoria, Durango. This specimen was sedated. Tissue samples from ear, hair and excrement were collected; samples of mtDNA were extracted and amplified, and two 418-bp sequences were obtained. The haplotype was characterized by a neutrality test of the control region. To determine the origin of the specimen, GenBank was searched for matches with haplotypes previously described and geographically characterized. Six 418-bp sequences were successfully amplified. The neutrality test yielded a single haplotype, with a $99.32 \%$ agreement with haplotype C. Haplotype C has been previously described for the Trans-Pecos region in Texas; accordingly, this haplotype belongs to the eastern subclade. The origin of the black bear specimen captured was Sierra Madre Oriental, based on the presence of haplotype C. This bear traveled at least $250 \mathrm{~km}$ to reach the municipality of Guadalupe Victoria. This displacement event indicates that connectivity between black bear populations from both Sierras Madres has been maintained. This distance is similar to displacements previously reported in fragmented environments where a suitable habitat is surrounded by arid zones. However, this displacement took place between two large mountain ranges, rather than within a single mountain range. Genetic diversity, frequency of displacement events between the Sierras, time and distance between displacements, dispersal routes and presence of patches of suitable habitat, are all factors that should be evaluated in order to understand the current dispersal and genetic-flow patterns between the subspecies of bears in Mexico.

El oso negro ha estado presente en Norteamérica desde hace tres millones de años; durante este periodo divergieron dos clados: el costero y el continental. Dentro del clado continental existen dos subclados (occidental y oriental), y el contacto entre ambos se considera un evento reciente. Debido a la alta diferenciación genética entre subclados, se considera que el flujo genético de las poblaciones entre la Sierra Madre Oriental y Occidental es de restringido a inexistente; además, ambientes áridos y los poblados humanos actúan como una barrera. En el estado de Durango no se cuentan con registros recientes de osos negros por lo que la captura de un individuo representa la oportunidad para probar si existe una conexión entre las poblaciones de la Sierra Madre Occidental y la Sierra Madre Oriental. Nuestro objetivo fue determinar el origen geográfico de este individuo y validar si existe una probable conexión entre poblaciones de ambas serranías. Se capturó un individuo de oso negro en el poblado Felipe Carrillo Puerto, municipio de Guadalupe Victoria, en Durango. El individuo fue químicamente inmovilizado y se tomaron muestras de tejido de la oreja, pelo y excremento. Se llevó a cabo la extracción de ADN mitocondrial (ADNmt) y se amplificó. Se obtuvieron dos secuencias de 418 pares de bases. Se caracterizó su haplotipo mediante un análisis de neutralidad de la región control. Para asociar la procedencia del individuo, se hizo una búsqueda en GenBank para determinar coincidencias con haplotipos previamente descritos y caracterizados geográficamente. Se amplificaron con éxito seis secuencias de 418 pb. El análisis de neutralidad arrojó un solo haplotipo, con una concordancia del $99.32 \%$ para el haplotipo C. El haplotipo C fue descrito para la región de Trans-Pecos en Texas, EUA; además, pertenece al subclado oriental. De este modo, la procedencia del oso negro capturado fue asociada a la Sierra Madre Oriental, México. El oso capturado, por el haplotipo encontrado, pertenece a la Sierra Madre Oriental, por lo que se desplazó al menos 250 km para llegar al Municipio de Guadalupe Victoria, Durango. Este evento de dispersión indica que la conectividad entre ambas Sierras Madres para los osos negros se mantiene. Esta distancia es similar a dispersiones previamente reportadas en ambientes fragmentados donde el hábitat adecuado está rodeado por zonas áridas. Sin embargo, este desplazamiento fue entre dos grandes sierras, y no sobre el mismo sistema montañoso. La diversidad genética, la frecuencia de eventos de dispersión entre las Sierras, el tiempo y distancia entre desplazamientos, las rutas de dispersión y la presencia de parches de hábitat adecuado, son factores a evaluar para entender los patrones de dispersión actual y el flujo genético entre las subespecies de osos presentes en México.

Key words: Connectivity; control region; dispersal; Durango; haplotype C; mitochondrial DNA; Ursus americanus.

C 2017 Asociación Mexicana de Mastozoología, www.mastozoologiamexicana.org

\section{Introduction}

The black bear (Ursus americanus, Pallas 1780) is a species that has inhabited North America for approximately three million years, during which it has extended across a broad geographical range (Kurten and Anderson 1980). This dis- tribution changed significantly during the Pleistocene as a result of the southward shift in the distribution pattern and extent of forests due to glaciation and post-glaciation events (Wooding and Ward 1997). This phenomenon favored the evolution of two clades - coastal and conti- 
nental — within the species (Pelletier et al. 20117). Within the continental clade, the distribution and topology of the diversity of mitochondrial DNA has revealed the existence of two subclades - eastern and western - that diverged in isolation between 1.8 and 0.8 million years ago (Wooding and Ward 1997; Van Den Bussche et al. 2009). These subclades have shown disjunct distributions over a long period of time, with refuges associated with forests to the east and west of their distribution range (Wooding and Ward 1997). Contact between both subclades in areas of Texas and New Mexico is considered a recent event (Wooding and Ward 1997).

The difference between these subclades is also evident within the southern limit of the distribution range of this species. The dominant haplotypes found for black bear populations in the Trans-Pecos region, Texas, have been identified as belonging to the eastern subclade (Onorato et al. 2004), while haplotypes described for northern Sonora, in western Mexico, belong to the western subclade (Varas et al. 2010).

Currently, due to the high genetic differentiation between subclades, it has been postulated that the gene flow between the populations inhabiting Sierra Madre Oriental and Sierra Madre Occidental in Mexico is non-existent (Onorato et al. 2004). The above has been proposed due to the existence of desert environments surrounding montane habitats, which act as barriers, in addition to present

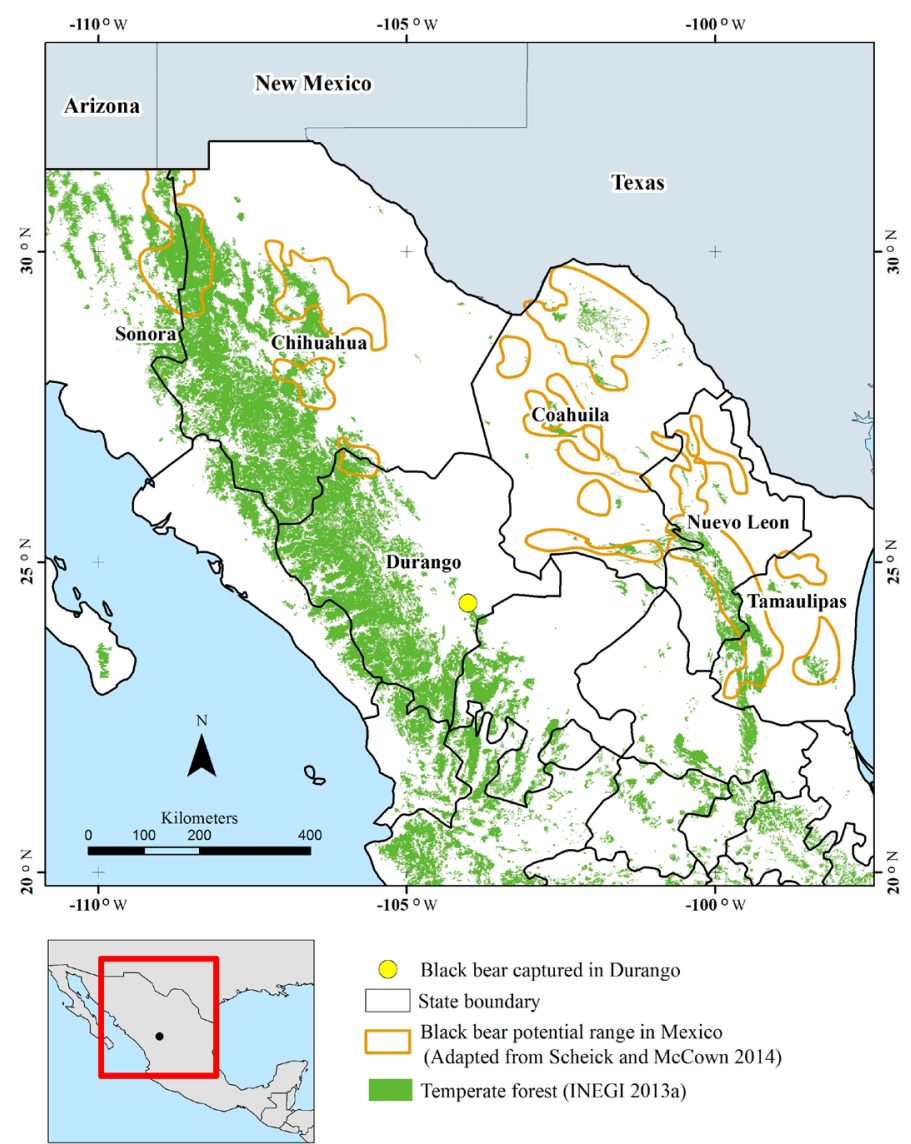

Figure 1. Record of a black bear specimen (Ursus americanus) captured in the municipality of Guadalupe Victoria, Durango, compared with the area of distribution of the species in Mexico (Scheick and McCown 2014). human activities and presence of towns and/or cities that prevent the displacement of individuals within an array of highly transformed habitats (Atwood et al. 2011).

In Mexico, the black bear is considered a species endangered in risk of extinction throughout most of its distribution range (DOF 2015), an area that was significantly reduced largely due to the impact of anthropogenic factors during the twentieth century. The presence of the species in the southern area of its distribution range in Mexico is characterized by a low number of records, and the precise limits of this range are still unknown (Delfín-Alfonso et al. 2011; Delfín-Alfonso et al. 2012; Scheick and McCown 2014). On April 2014, one black bear specimen was captured by local inhabitants in Felipe Carrillo Puerto, a town located in the municipality of Guadalupe Victoria, state of Durango. Durango is one of the states where there is a high uncertainty about the presence of the black bear (Delfín-Alfonso et al. 2012; Juárez-Casillas and Varas 2013); prior to this capture, there had been no recent records of the species in the area (Delfín-Alfonso et al. 2011). The presence of the specimen in this locality raise questions about its geographical origin, whether associated with the Sierra Madre Occidental or the Sierra Madre Oriental. This specimen brought the unique opportunity to investigate the possible existence of a recent connectivity event between both regions; accordingly, our aim was to determine the geographic origin of the black bear specimen by characterizing its haplotype.

\section{Materials and Methods}

Study area. Felipe Carrillo Puerto ( $\left.24^{\circ} 27^{\prime} \mathrm{N},-40^{\circ} 07^{\prime} \mathrm{W}\right)$ is one of the largest urban localities in the municipality of Guadalupe Victoria; it is located to the southeast of the state of Durango, with a population of 2,000 inhabitants. The town is surrounded by rainfed agriculture fields that make up $51 \%$ of the municipality area, while natural grasslands rank second in terms of coberture ( $28 \%)$, and pine and oak forests comprise less than $4 \%$ of the municipality area (INEGI 2013a). Mean annual precipitation ranges between $450 \mathrm{~mm}$ and $605 \mathrm{~mm}$ per year, and mean annual temperature, between $12.7^{\circ} \mathrm{C}$ and $17.4^{\circ} \mathrm{C}$. The elevation within the municipality varies from 1,912 to 2,560 m (INEGI 2013b).

Capture and Maintenance of the Black Bear Specimen. The black bear specimen was captured on 23 April 2014 by two local inhabitants of Felipe Carrillo Puerto using ropes. Once the specimen was securely held, the local inhabitants informed the authorities concerned. On the first veterinary examination at the site of the capture, personnel from PROFEPA Durango and the Sahuatoba Zoo mentioned that the specimen was in good health condition (PROFEPA 2014).

The specimen captured was transferred by PROFEPA Durango to the Sahuatoba Zoo, in the city of Durango, where he was sedated by the local staff $(2 \mathrm{mg} / \mathrm{kg}$ each of ketamine/xylazine). Once sedated, this specimen was identified as a young male (approximately two years old based on dental wear) and its somatic measurements were recorded $(\mathrm{LT}=1.540, \mathrm{LC}=90, \mathrm{LP}=220,116, \mathrm{~W}=81.5)$; 
the specimen was in good physical condition. During the examination, samples of ear tissue, hair and feces (two replicates of each) were collected for processing at Universidad Autónoma de Queretaro; afterwards, the specimen was fitted with a radio transmitter collar.

Haplotype Characterization. For DNA extraction, $30 \mathrm{mg}$ of tissue, $0.50 \mathrm{~g}$ from the surface of excrement, and three hairs were collected from each sample. For tissue and hair samples, the DNeasy Blood \& Tissue mini kit (Qiagen Inc., Valencia, California) was used following the manufacturer's protocols. For stool samples, the QIAmp ${ }^{\circledR}$ DNA Stool mini kit (Qiagen Inc., Valencia, California) was used following the protocol developed by Varas et al. (2010). To confirm the proper operation of the protocol and the amplification and sequencing procedure, we used a negative control (high purity water for $\mathrm{PCR}$ ) and a positive control (previously identified black bear DNA sample).

Once the mitochondrial DNA was extracted, it was amplified by PCR. Two sequences of 418 base pairs were obtained using a portion of the cytochrome $b$ region and $D$-loop of mitochondrial DNA, using the primer ADNmtCRf (CTCCACTATCAGCACCCAAAG) and its inverse ADNmtCRr (GGAGCGAGAGGTACACGT) with a volume of $15 \mathrm{ml}$, where $9 \mathrm{ml}$ were green taq (PROMEGA Corp.), $0.2 \mathrm{ml} \mathrm{BSA} 7.5 \%$ (SigmaAldrich, St. Louis, MO, USA), 0.2 ml MgCl2 (QIAGEN, Inc.), 0.3 $\mathrm{ml}$ of each primer, and $5 \mathrm{ml}$ of DNA (Rinkevich 2012).

Initial denaturation was carried out at $95^{\circ} \mathrm{C}$ for $10 \mathrm{~min}$ utes, followed by 40 denaturation cycles at $94^{\circ} \mathrm{C}$ for $45 \mathrm{sec}$ onds, hybridization at $54^{\circ} \mathrm{C}$ for one minute, extension at 72 ${ }^{\circ} \mathrm{C}$ for two minutes, final extension at $72{ }^{\circ} \mathrm{C}$ for 10 minutes, and cooling at $4^{\circ} \mathrm{C}$ (Short Bull et al. 2011). The resulting amplifications were subjected to electrophoresis through $1.5 \%$ agarose gel with TBE buffer (Onorato et al. 2004) and were visualized through exposure to UV rays. Amplifications were purified using the Wizard PCR Prep DNA Purification System (Promega, Madison, Wisconsin).

The amplified sequences were sent to Macrogen Sequencing Service http://dna.macrogen.com/esp for sequencing. Afterwards, sequences were reviewed and aligned in the program Sequencher 4.6 (Gene Codes Corporation, USA). To determine the haplotypes in the sequences analyzed, ADNmtCR was tested for neutrality using the program dnasp5 (Avin 2012). Finally, GenBank (NCBI http://www.ncbi.nlm.nih.gov/) was searched for potential matches with haplotypes previously described and characterized geographically (Onorato et al. 2004; Varas et al.2010, Van Den Bussche et al. 2009; Pelletier et al. 2011), aiming to associate the origin of the black bear with either the Sierra Madre Oriental or the Sierra Madre Occidental.

\section{Results}

The DNA from the six samples of the black bear specimen were successfully amplified (Table 1); thus, all were used in the haplotype characterization analysis. The neutrality test yielded a single haplotype. Sequences of 418 base pairs were obtained and the number of base pairs that were not amplified per sample ranged from 1 to 6 . Considering these base pairs as unknown, our samples yielded an agreement of $99.32 \% \pm 0.41$ (std dev.) with haplotype $C$ described by Onorato et al. (2004) (Table 1).

Based on the above findings, the black bear specimen captured in the municipality of Guadalupe Victoria, Durango, comes from the subclade inhabiting Sierra Madre Oriental.

\section{Discussion}

The bear captured in Felipe Carrillo Puerto, Durango, belongs to the eastern subclade representing the populations of Sierra Madre Oriental, since haplotype $C$ has not been recorded in Sierra Madre Occidental (Varas et al.2010). Haplotype $C$ was first described in 2004 from a single specimen inhabiting the Trans-Pecos region, Texas, USA, and has been recently documented in Louisiana (Van Den Bussche et al. 2009). It is considered that haplotype B gave rise to haplotypes $C$ and $A$. Haplotype B is considered the parent haplotype within the eastern subclade, being broadly distributed from Minnesota in northern United States to Mexico. Van Den Bussche et al. (2009) consider that colonization by this set of haplotypes (A, B, and C), which are characteristic of the eastern lineages, took place gradually from east to west given the absence of barriers that would restrain gene flow.

The specimen captured in Durango traveled more than $250 \mathrm{~km}$ from the area recognized as a part of the known distribution range of the black bear in Coahuila to reach the municipality of Guadalupe Victoria (Scheick and McCown

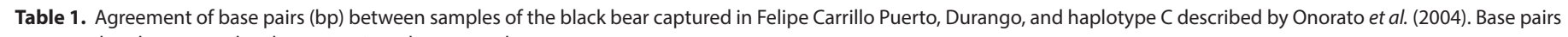
1-3 correspond to the start codon; bp 416-418, to the stop codon.

\begin{tabular}{|c|c|c|c|c|c|c|c|c|c|c|c|c|c|c|c|c|c|c|c|c|}
\hline \multirow{2}{*}{ Sample } & \multicolumn{19}{|c|}{ Position of non-amplified (-) base pairs } & \multirow{2}{*}{ Agreement (\%) } \\
\hline & 1 & 2 & 3 & 5 & 13 & 17 & 21 & 30 & 39 & 43 & 55 & 104 & 127 & 288 & 405 & 414 & 416 & 417 & 418 & \\
\hline Tissue & G & A & A & - & A & $\mathrm{T}$ & $\mathrm{T}$ & - & C & $\mathrm{T}$ & $\mathrm{C}$ & C & $\mathrm{T}$ & A & A & $\mathrm{T}$ & G & G & $\mathrm{T}$ & 99.52 \\
\hline Tissue & G & A & A & A & A & $\mathrm{T}$ & $\mathrm{T}$ & $\mathrm{T}$ & $C$ & $\mathrm{~T}$ & $C$ & - & $\mathrm{T}$ & A & A & $\mathrm{T}$ & G & G & $\mathrm{T}$ & 99.76 \\
\hline Excrement & G & A & A & A & - & $\mathrm{T}$ & - & $\mathrm{T}$ & - & $\mathrm{T}$ & $C$ & $C$ & $\mathrm{~T}$ & A & A & $\mathrm{T}$ & G & G & $\mathrm{T}$ & 99.28 \\
\hline Excrement & G & A & A & - & A & $\mathrm{T}$ & $\mathrm{T}$ & $\mathrm{T}$ & C & $\mathrm{T}$ & - & C & - & $A$ & A & $\mathrm{T}$ & G & G & $\mathrm{T}$ & 99.28 \\
\hline Hair & G & A & - & A & A & - & $\mathrm{T}$ & - & C & - & C & C & $\mathrm{T}$ & A & - & - & G & G & $\mathrm{T}$ & 98.56 \\
\hline Hair & G & A & A & - & $A$ & $\mathrm{~T}$ & $\mathrm{~T}$ & $\mathrm{~T}$ & C & $\mathrm{T}$ & $\mathrm{C}$ & C & $\mathrm{T}$ & - & $A$ & $\mathrm{~T}$ & G & G & $\mathrm{T}$ & 99.52 \\
\hline Haplotype C & G & A & A & A & A & $\mathrm{T}$ & $\mathrm{C}$ & G & C & $\mathrm{T}$ & $\mathrm{C}$ & A & $\mathrm{T}$ & A & A & $\mathrm{T}$ & G & G & $\mathrm{T}$ & \\
\hline
\end{tabular}


2014). This dispersal event by a relatively young individual strongly supports the fact that the connectivity between the Sierra Madre Occidental and the Sierra Madre Oriental is currently maintained for black bears.

Black bear males are capable of carrying out extensive dispersal events in desert environments within a mountain range. There are reports about the displacement of males covering between 45 and $282.2 \mathrm{~km}$ in straight line; these movements have been attributed to a fragmented environment where a suitable habitat is surrounded by grassland or arid areas (Costello et al. 2001; Hellgren et al. 2005; Liley and Walker 2015). The bear specimen reported herein followed a route similar to the one reported previously. However, this individual extensive displacement connected the two largest mountain ranges of Mexico passing through a landscape matrix dominated by desert conditions, which are considered for the species relative to temperate forests (Costello et al. 2001).

Since a single black bear individual — and hence a single haplotype - was available (Van Den Bussche et al. 2009), the presence of more individuals in Sierra Madre Occidental coming from Sierra Madre Oriental is currently unknown. Although we cannot be certain that the specimen captured comes from the wild, it showed some features that so indicate. On the one hand, the specimen lacked the calluses on pads and joints that are typical in animals that have spent time in captivity. However, the behavior of the specimen after its release was consistent with the one of a wild animal. The specimen was released by Durango PROFEPA and CONANP staff in La Michilía Biosphere Reserve less than a week after its capture. From the time of release, its displacements were recorded through satellite location over a period of 19 months; it traveled the desert between the two mountain ranges heading to Sierra Madre Oriental (unpublished data).

The genetic diversity, as well as the frequency of dispersal events between the two Sierras Madres, the time and distance between displacement events, the likely dispersal routes and the presence of patches of suitable habitats, are all factors that should be assessed to understand the current dispersal and gene-flow patterns between the subspecies of bears in Mexico.

\section{Acknowledgments}

We are grateful to PROFEPA, PROFAUNA A. C. and the Sahuatoba Zoo, Durango, for the logistical support provided. We would also like to thank Universidad Autónoma de Querétaro for the economic support and the use of its facilities to carry out the genetic analysis. María Elena Sánchez-Salazar translated the manuscript into English.

\section{Cited literature}

Atwood, T. C., J. K. Young, J. P. Beckmann, S. W. Breck, J. Fike, O. E. RHODES, AND K. D. BRISTOW. 2011. Modeling connectivity of black bears in a desert sky island archipelago. Biological Conservation 144:2851-2862.
AviN, F. A. 2012. Phylogenetics analyses manual (Chromas 2.1, Mega4. 0, Arlequin 3.5, DNAsp 5, TCS 1.21, Network 4.6). Retrieved from http://eprints.um.edu.my/9797/

Costello, C. M., D. E. Jones, K. A. Green-Hammond, R. M. Inman, K. H. Inman, B. C. Thompson, R. A. Deitner, and H. B. Quigley. 2001. A study of Black Bear Ecology in New Mexico with Models for Population Dynamics and Habitat Suitability. Final Report, Federal Aid in Wildlife Restoration Project W-131-R, New Mexico Department of Game and Fish. Santa Fe, U. S. A.

Delfín-Alfonso, C. A., C. A. López-González, and N. E. Lara-Díaz. 2011. El oso negro americano en el noroeste de México: Recuperación de registros de ocurrencia. Acta Zoológica Mexicana (n. s.) 27:777-801.

Delfín-Alfonso, C. A., C. A. López-González, and M. Equihua. 2012. Potential distribution of American black bears in Northwest Mexico and implications for their conservation. Ursus 23:65-77. DOF. 2015. Proyecto de modificación del Anexo Normativo III, Lista de especies en riesgo de la Norma Oficial Mexicana NOM-059-SEMARNAT-2010, Protección ambiental. Especies nativas de México de flora y fauna silvestres. Categorías de riesgo y especificaciones para su inclusión, exclusión o cambio. Lista de especies en riesgo. Diario Oficial, cuarta sección. México.

Hellgren, E. C., D. P. Onorato, and J. R. Sklles. 2005. Dynamics of a black bear population within a desert metapopulation. Biological Conservation 122:131-140.

INEGI. 2013a. Conjunto Nacional de Información de Uso del Suelo y Vegetación escala 1:250,000, Serie V. INEGI. Aguascalientes, México.

INEGI. 2013b. Continuo nacional de elevaciones resolución $30 \mathrm{~m}$. Instituto Nacional de Estadística y Geografía. México. http://www.inegi.org.mx/geo/contenidos/datosrelieve/ continental/continuoelevaciones.aspx

Juárez-Casillas, L. A., AND C. Varas. 2013. Black bears in Mexico, an update of literature review. Therya 4:447-465.

KuRtén, B., AND E. Anderson. 1980. Pleistocene mammals of North America. Columbia University Press. New York, U. S. A. LILEY, S. G., AND R. N. WALKer. 2015. Extreme movement by an American black bear in New Mexico and Colorado Ursus 26:1-6.

Onorato, D. P., E. C. Hellgren, R. A. Van Den Bussche, and D. L. DOAN-CRIDER. 2004. Phylogeographic patterns within a metapopulation of black bears (Ursus americanus) in the American Southwest. Journal of Mammalogy 85:140-147.

Pelletier, A., M. E. Obbard, B. N. White, C. Doyle, AND C. J. Kyle. 2011. Small-scale structure of American black bears illustrates potential postglacial recolonization routes. Journal of Mammalogy 92:629-644.

PROFEPA. 2014. Asegura PROFEPA oso que deambulaba en municipio Guadalupe Victoria, Durango. Disponible en (available at) http://www.profepa.gob.mx/ innovaportal/v/5944/1/mx/asegura profepa oso que deambulaba en municipio guadalupe victoria durango. $\underline{\mathrm{html}}$

RinKEVICH, S. E. 2012. An assessment of abundance, diet, and cultural significance of Mexican gray wolves in Arizona. Dissertation. University of Arizona. Tempe, U. S. A.

SCheICK, B. K., AND W. McCown. 2014. Geographic distribution of American black bears in North America Ursus 25:24-33. 
Short Bull, R. A., S. A. Cushman, R. Mace, T. Chilton, K. C. Kendall, E. L. Landguth, M. K. Schwartz, K. McKelvey, F. W. Allendorf, and G. LUIKART. 2011. Why replication is so important in landscape genetics: American black bear in the Rocky Mountains. Molecular Ecology 20:1092-1107.

Van Den Bussche, R. A., J. B. Lack, D. P. Onorato, and L. C. GardnerSANTANA. 2009. Mitochondrial DNA phylogeography of black bears (Ursus americanus) in central and southern North America: Conservation implications. Journal of Mammalogy 90:1075-1082.

Varas, C., C. A. López-González, J. Ramirez, P. Krausman, and M. Culver. 2010. Conservation genetics of black bears in the Sky Islands of Arizona and Northern México. Pp. 275-281 in Southwestern Desert Resources (Halvorson, W., C. van Ripper, and C. Schwalbe, eds.). University of Arizona Press. Tucson, U.S. A.

WoodING, S., AND R. WARD. 1997. Phylogeography and Pleistocene evolution in the North American black bear. Molecular Biology and Evolution 14:1096-1105.

Associated editor: Jorge Servin

Submitted: April 2, 2017; Reviewed: May 17, 2017;

Accepted:July 10, 2017; Published on line:September 26, 2017. 
